\title{
The Impact of Triple Bottom Line Accounting on Firms' Sustainability in Nigeria
}

\author{
Olaoye, Ayoola Azeez \\ Bsc (Ed), (Acct), Msc (Acct) \& ACA
}

Doctoral Student, School of Post Graduate Studies, Faculty of Management Sciences, Department of Accounting, Ekiti State University, Ado-Ekiti, Nigeria

\author{
Dr. E. T.Olatunji \\ Senior Lecturer, Accounting Department, Ekiti State University, Ado-Ekiti, Nigeria
}

\begin{abstract}
The era of reporting business activities solemnly based on financial performance is over. In addition to economic performance reporting, many organizations in the globe have been producing entities' reports that disclose and account for the social responsibilities and environmental impacts of the entities. Also, the accounting financial reporting practice is considered socially and environmentally unfriendly. This study therefore, examines the impact of triple bottom line accounting on firms' sustainability in Nigeria by focusing on the perspective views of firms' stakeholders. A survey research design was employed and the population of this study is made up of three selected money deposit banks in Nigeria. Purposive sampling technique was used to select the sample of 150 respondents. The primary data was collected through a structured questionnaire and the data gathered was analyzed using descriptive statistic and multiple regression models with the aid of SPSS version 20. Findings from this study indicate that $\mathrm{p}$-value of $0.00<001$. Therefore, the triple bottom line accounting has significant impact on firms' sustainability in Nigeria. This study concludes that disclosure in form of TBL accounting becomes a necessity to satisfy the interest of varying stakeholder groups and to place firms' sustainability objective at the fore front of present day business. This study therefore, recommends that firms should adopt transparent disclosure of quantifiable triple bottom line accounting encompassing social, environmental and economic performance as this would boost stakeholder's confidence and improve the overall quality of their report. Also, the performance information reported by firms should be linked with their stated intentions and their strategic processes for achieving sustainability as these would ultimately capture their impact in the society and boost their reputation. Then as most of the developed countries have various forms of standards regulating social and environmental disclosure, the governments of developing countries especially Nigeria are encouraged along with standard setting bodies to develop standards that can guide every organization in accounting for social and environmental impacts and. Finally, additional education and training should be given to accountants on the key trends in the areas of economic, social and environmental disclosure so as to keep them abreast of changes in the profession.
\end{abstract}

Keywords: Accounting, Firms, Sustainability, Triple bottom line.

DOI: $10.7176 /$ RJFA/11-9-06

Publication date:May $31^{\text {st }} 2020$

\section{Introduction}

The traditional and dominant focus for external corporate reporting in Nigeria has been to provide information about an organization's financial (or economic) performance alone (Onyali, Okafor \& Onodi, 2015). However over the years, increasing number of organizations in both the private and public sectors have been developing TBL accounting processes to report their performance (Wang et al, 2007). Triple Bottom Line (TBL) reporting is a concerted effort to incorporate economic, environmental and social considerations into a company's performance evaluation and decision making processes (Faux, 2004; Wang \& Lin, 2007). This type of reporting establishes principles by which a company should operate in order to concentrate on the total effect of their actions either positive or negative (Faux, 2004). John Elkington in 1997 coined "triple bottom line" as a new term to advance his sustainability agenda. Elkington (1998) wrote on sustainable development involving simultaneous pursuit of economic prosperity, environmental quality, and social equity (Amos, \& Atu, 2016). TBL is a clear concept that based on the combination of social, environmental, and economic lines (bottoms) of reporting the activities of a business (Onyali et al, 2015). For the past many years, corporate organizations all over the world have being reporting greater amounts of non-financial information about their operations because it has become a great concern that the natural resources on which the firms placed reliance are being consumed at a rate much faster than the level they can be replenished (Michael, Allan, \& Penny, 2008).

However, organizations have come to realize that meeting stakeholder expectations as a condition for sustainability is as necessary a as the need to achieve overall strategic business objectives (Ballou, Heitger \& 
Landes, 2006). As the human society progresses leading to a more obvious interrelationship and interdependence between business and society, different interest groups have begun mounting pressure on business organizations to assume more responsibilities for the society in which they operate, beyond their economic function (Osisioma, 2010). If maximizing shareholder value continues to be an overriding concern, companies will not be able to meet other key stakeholder interests of environmental and social sustainability of a business (Crowther, 2000). The capacity of a firm to generate sustainable wealth over time, and hence its long-term value, is determined by its relationships with critical stakeholders and any stakeholder relationship may be the most critical one at a particular time or on a particular issue. These relationships influence the way a company is governed and, in turn, is influenced by the company's behavior (Deegan, 2001). The number of sustainability-related trends such as global water needs, changes in global climate, and energy demands has created an uncertain business environment in which new issues, legislation, stakeholder expectations, and technologies must be considered. This has led to the growing demands from stakeholders for more extensive information about the operations and financial standing of businesses by encouraging some companies to include information on triple bottom lines of sustainability on their annual accounts and reports (Amos et al, 2016).

Today accountability requires the corporate world to extend their information beyond financial data by enhancing TBL to connect the financial reporting with the business's everyday activities in a way that provides a broader awareness of the impact of the firms upon society (Jesh \& Stasiskiens, 2005). By adopting TBL accounting, businesses would understand that they are being held to specific principles developed by internal and external forces in the organizations. For this reason, firms would need to focus on the impact that their operations have on the community in which they operate (Okafor, Okaro \& Egbumike, 2013). Aside that, the financial reporting practice of the entities in Nigeria is considered socially and environmental unfriendly, and economic accounting was also accused of contributing to the escalation of environmental damages, and ecological and social crisis because the financial statements that are the output of the accounting process and the basis of consideration in the assessment and decision making of the parties involved only provide financial accounting information, while social and environmental accounting information tends to be ignored or misguided in accounting treatment, recording and reporting of information leading to the judgments and decisions made by the users especially regarding social and environmental aspects to be erroneously misguided. It is against the background of these gaps that this study seeks to examine the impact of TBL accounting on firms' sustainability in Nigeria. Specifically, this study will also explore sustainability and the triple bottom line as tools to examine, appraise or measure the effects of business activities on the economy, social equity, and environment. Findings from this study will create more awareness on the necessity of stakeholders of firms to embrace triple bottom line accounting strategy in reporting their businesses in Nigeria.

\section{Conceptual Review}

\subsection{Triple Bottom Line Accounting}

The concept of Triple Bottom Line (TBL) was developed by John Elkington in 1997. John Elkington created a new framework to measure both financial and non-financial performance during the mid-1990s (Suttipun, 2012). The term "Triple bottom line" of Elkington (1998) emphasizes that sustainability has three dimensions: Economic prosperity, environmental quality and the social justice (The element which businesses had preferred to overlook) (Michael et al, 2008). TBL stresses that the pursuit of sustainable development is not just only in reconciling potential conflicts between economic growth and ecological sustainability but also a social dimension for sustainability (Ballou et al, 2006). The TBL is a simple and increasingly popular way to organize firms' action for sustainability (Michael, Allan \& Penny, 2008). There are three main focuses of TBL: People, planet, and profit (Global Reporting Initiative, 2000). The key to corporate sustainability is the concept of the triple bottom line which means that business success is no longer defined only by monetary gains but also by the impact an organization's activities have on society as a whole. In recent years a deal of attention has been directed to triple-bottom-line reporting defined by Elkington (1997) as reporting that provides information about the economic, environmental and social performance of an entity (Ballou et al, 2006). The notion of reporting based on these three components (bottom lines) is directly tied to the concept and goal of sustainable development (Amos et al, 2016).

Triple bottom line reporting, if properly implemented, will provide information to enable others to assess the sustainability of organizations' operations (Michael et al, 2008). The perspective taken is that for an organization to sustain, it must be financially secured, as evidenced through such measures as profitability; it must minimize, or ideally eliminate its negative environmental impacts and it must act in conformity with societal expectations. These three factors are obviously highly inter-related (Perrius \& Tencat, 2006). Triple Bottom Line (TBL) accounting is a method used in business accounting to further expand stakeholders' knowledge of the company. It goes beyond the traditional, financial aspects and reveals the company's impact on the world around it (Ballou et al, 2006). TBL is a concerted effort to incorporate economic, environmental and social considerations into a company's evaluation and decision making processes (Wang et al, 2007). Triple 
Bottom Line is a clear concept that based on the combination of social, environmental, and economic lines (bottoms) of reporting the activities of a business for sustainability (Amos et al, 2016).

Triple Bottom Line Accounting (TBLA) refers to a method of measuring the economic, environmental, and community service impacts of an organization rather than the traditional practice of measuring just the financial bottom line (Amos et al, 2016). Triple Bottom Line Accounting (TBLA) or sustainability accounting focuses on the value to society that is created or destroyed by an organization's activities or business (Ballou et al, 2006). Richardson (2004) identifies two high level components of the TBLA framework. First is the restatement of traditional accounts to highlight financial flows that are sustainability related; second is additional accounting undertaken to show the financial value of economic, environmental, and social performance upon external stakeholders. Richardson (2004) highlights the danger inherent in accounting for only those items that can be reduced to monetary value and the difficulties of converting environmental practices and performance into financial values, much less the extension to the sphere of social performance and impact. Richardson (2004) also stresses that financial valuation of economic, environmental, and social bottom lines places these factors into silos that allows them to be traded-off against one another. Richardson (2004) argues for moving beyond this thinking to a systemic approach that focuses upon qualitative processes such as diversity, learning, adaptation, and self-organization rather than defining and setting of financial, environmental, and social performance targets to be achieved and perhaps traded-off against one another.

Many organizations have adopted the TBL framework to evaluate their performance in a broader perspective to create greater business value. In traditional business accounting and common usage, the "bottom line" refers to either the "profit" or "loss", which is usually recorded at the very bottom line on a statement of revenue and expenses (Ballou et al, 2006). Over the last five decades, environmentalists and "social justice" advocates have struggled to bring a broader definition of bottom line into public consciousness by introducing full cost accounting. For example, if a corporation shows a monetary profit, but their asbestos mine causes thousands of deaths from asbestosis, and their copper mine pollutes a river, and the government ends up spending taxpayers' money on health care and river clean-up, how do we perform a full societal cost benefit analysis? It is on this basis that the triple bottom line adds two more "bottom lines": social and environmental (ecological) concerns. With the ratification of the United Nations, TBL standard for urban and community accounting in early 2007 became the dominant approach to public and private sectors full cost accounting (Global Reporting Initiative, 2006). The framework of TBL focuses on the interrelated dimensions of profit, people, and the planet (Suttipun, 2012).

Businesses have full control over what is put into their reports, but a considerable amount of the authority comes from external stakeholders, whose input is vital. The Sustainability Committee considers input from internal and external stakeholders and determines the significant topics to report (Mitchell, et al., 2008). The TBL report itself should be led by the mission and vision statement of the company. These statements should outline the businesses goals for short and long-term. Information determined to be important must be included. A company should not withhold information on the basis of its undesirable results. Once the reporting standards have been set, information based on those guidelines should be continuously reported so that the report is dependable and relays the information consistently (Ballou et al, 2006).

\subsubsection{Triple Bottom Line Frameworks}

Triple Bottom Line is an accounting framework that incorporates three lines of economic, social and environment (Onyali et al, 2015).

\subsubsection{Economic Line}

The economic line of TBL framework refers to the impact of the organization's business practices on the economic system (Elkington, 1998). It pertains to the capability of the economy as one of the subsystems of sustainability to survive and evolve into the future in order to support future generations (Spangenberg, 2005). The economic line ties the growth of the organization to the growth of the economy and how well it contributes to support it. In other words, it focuses on the economic value provided by the organization to the surrounding system in a way that prospers it and promotes for its capability to support future generations (Onyali et al, 2015).

\subsubsection{Social Line}

The social line of TBL refers to conducting beneficial and fair business practices to the labour, human capital, and the community (Elkington, 1997). The idea is that these practices provide value to the society and "give back" to the community. Examples of these practices may include fair wages and providing health care coverage. Aside from the moral aspect of being "good" to the society, disregarding social responsibility can affect the performance and sustainability of the business. Recent examples in the industries have revealed that there are economic costs associated with ignoring social responsibility. Simply put, the social performance focuses on the interaction between the community and the organization and addresses issues related to community involvement, employee relations, and fair wages (Goel, 2010; Onyali et al, 2015).

\subsubsection{Environmental Line}

The environmental line of TBL refers to engaging in practices that do not compromise the environmental 
resources for future generations. Sustainable development is considered the development that meets the needs of the present without compromising the ability of the future generations to meet their own needs (Onyali et al, 2015). It pertains to the efficient use of energy recourses, reducing greenhouse gas emissions, and minimizing the ecological footprint, etc. (Goel, 2010).

\subsubsection{Challenges of TBL Accounting Practices}

A challenge with the triple bottom line accounting is that it is difficult to compare the people and planet accounts in terms of cash and the way the profit account is measured. The three separate accounts cannot be added or combined, and must be considered separately (Jasch et al, 2005). Also, the Critics of TBL include Norman and MacDonald (2004) who question whether the paradigm of TBL is anything but a marketing strategy. Norman et al (2004) argue that, prior to the TBL model, the belief in attaining corporate social responsibility (CSR) had already led to a broader movement sometimes referred to as Social and Ethical Accounting, Auditing, and Reporting (SEAAR), producing a variety of competing standards (Onyali et al, 2015). In terms of implementing TBL, there are no generally or widely accepted accounting standards or metrics to measure environmental or social performance (Adams, Frost \& Webber, 2004). While managers' attention to the social and environmental impacts of their organizations has increased, it is difficult to develop standard accounting similar to those in financial accounting (Mintz, 2011). Mintz recommends that organizations should develop Key Performance Indicators (KPI) or quantifiable measures linked to their own missions, goals, and stakeholder expectations. Care should be taken as businesses need to internalize their social and environmental impacts they also need to instill the realities of the economic environment into their environmental and social policies (Rogers \& Hudson, 2011). Also, several arguments are currently being made against Triple Bottom Line Reporting. According to prior studies, one worry is the possibility that a company's actions might not support their intentions (Michael et al, 2008). The companies declare that they intend to take on the challenges of becoming more socially and ecologically accountable, but the only proof of that is mere pieces of paper or pretty plaques on the organization's wall (Mitchell, Curtis, \& Davidson, 2008; Painter-Morland, 2006). In many cases, companies have allowed appropriate reporting to be influenced by corporate supremacy. This indicates that, to some extent, abiding by the guidelines of TBL can be difficult to maintain (Ballou et al, 2006). More so, if TBL is added to a company's report process, the additional time could initially negatively affect their bottom line, increasing the task complexity of their operations (Skouloudis, Evangelinos, \& Kourmousis, 2009). Not only is the scoring of the company to determine how well the operations are matching the goals time consuming, but also the execution of new procedures and training required to prepare employees for the new tasks can be expensive (Michael et al, 2008).

Furthermore, companies, which already have overloaded employees, will need to add additional responsibilities in order to incorporate and measure these new procedures. Additional work is additional stress on their labor resources. An individual's stress associated with work creates multiple problems not only for that person but also for the company in poor health, absenteeism, decreased job satisfaction, and an unstable emotional state (Ballou et al, 2006). As a company strives to meet the goals of sustainability, opponents may focus on the ethical problems uncovered through the process. Accusations by critics could lead to poor company perception while the company undertakes a shift to a new more socially sound environmental focus (Ballou et al, 2006). Critics are typically "slow to praise and quick to criticize" (Mish \& Scammon, 2010). With this potential initial backlash, companies might be hesitant to embrace a sustainability agenda, or become extremely introverted during the shift toward TBL reporting (Ballou et al, 2006).

\subsubsection{Benefits of Triple Bottom Line Practices}

TBL is a societal and ecological agreement between the community and businesses. TBL reporting incorporates presenting what the business is doing well, along with areas that need improvement. Reporting in this way demonstrates a drive towards increased transparency, which can mitigate concerns by stakeholders on hidden information (Michael et al, 2008). Also, including TBL reporting demonstrates to stakeholders that the business is taking accountability to a higher level. This reporting maintains and raises expectations of companies and improves global clout (Ho \& Taylor, 2007). The process of building a sustainable environment can lead to other revelations on how the business world can lend a helping hand in protecting the natural resources that are quickly evaporating (Ballou et al, 2006). Despite those challenge, the TBL framework enables organizations to take a longer-term perspective and thus evaluate the future consequences of decisions (Slaper \& Hall (2011). And despite all the criticisms against TBL and Elkington's original definition, the TBL concept continues to be important in thinking about sustainability and its application to management in both for-profit and public spheres. Finally, one can argue that companies have a social responsibility to be accountable for the resources that they use and waste. Reporting on a company's sustainability gives a benchmark for the future (Michael et al, 2008; Ballou et al, 2006).

\subsection{Concept of Sustainability}

The companies aiming for sustainability need to perform not only a single, financial bottom line but also the triple bottom line (Onyali et al, 2015). Elkington's definition intends to go beyond previous constructions of 
sustainable development and corporate social responsibility to encompass an approach that emphasizes economic prosperity, social development and environmental quality as an integrated method of doing business. This definition implies a shift away from the emphasis of organizations on short-term financial goals to longterm social, environmental, and economic impacts (Ballou et al, 2006; Michael et al, 2008; Onyali et al, 2015). Sustainability can also be defined as an overarching conceptual framework that describes a desirable, healthy, and dynamic balance between human and natural systems; a system of policies, beliefs, and best practices that will protect the diversity and richness of the planet's ecosystems, foster economic vitality and opportunity, and create a high quality of life for people and, a vision describing a future that anyone would want to inhabit (Amos et al, 2016). Central to these definitions is the applicability of sustainability to three elements of life: economic or financial considerations, environmental protection and stewardship, and community and individual human well-being: the triple bottom line of sustainability. This means improving the economic and social quality of life while limiting impacts on the environment to the carrying capacity of nature. In this framework, ideal solutions to any type of challenge will generate long-term benefits in all three areas (Ballou et al, 2006).

In the early $1990 \mathrm{~s}$, following trends in other countries, some companies started offering information about their environmental performance. Initially, the information was provided (voluntarily) in the annual report and tended to be self-mandatory (Michael et al, 2008). From about the mid-1990s, the standard of environmental performance reporting arguably improved as various environmental reporting guidelines were issued internationally (Ballou et al, 2006). The growth of this broader "world sustainability" viewpoint can be seen in the number of companies that have begun reporting on more than just financial operations. Large corporations such as Weyerhaeuser Company, The Boeing Company, PricewaterhouseCoopers, The Procter \& Gamble Company, Sony Corporation, and Toyota Motor Corporation, have joined with many others to create the World Business Council for Sustainable Development (WBCSD, 2010), which focuses on creating a pathway to a world that will require fundamental changes in governance structures, economic frameworks, and business and human behaviour. This council states that the changes are necessary, feasible and offer tremendous business opportunities for companies that turn sustainability into strategy (Ballou et al, 2006). A move toward additional sustainability reporting can be seen in companies and governmental entities in a variety of countries ((Michael et al, 2008).

One of the purposes of sustainability for any business is to reduce or eliminate its cost of poor quality. Measuring the cost of poor quality is a vital part in TBL reporting (Isaksson, 2005). In order to avoid any selfserving bias when undertaking this task, the company needs to have an evaluation done by a committee. One of the ways this can be handled is to use a section of the Board of Directors to preside as a Sustainability Committee of the Board (Painter-Morland, 2006). This will broaden the perspective for changes that need to be made to create a higher level of sustainability. After reporting topics have been decided, a review should be undertaken by individuals who were not involved in the gathering process. All collected information needs to be checked for accuracy and the data organized into the TBL report. Details that are not vital to the report should be excluded and any jargon avoided. The report should be straightforward and understandable by the stakeholders, both employees and stockholders.

\subsection{Theoretical Review}

This study is anchored on the stakeholder theory. The stakeholder theory was coined by Freeman R Edward in 1984. Freeman's stakeholder theory explains specific corporate actions and activities using a stakeholder-agency approach, and is concerned with how relationships with stakeholders are managed by companies in terms of the acknowledgement of stakeholder accountability (Freeman, 1984). The argument of Freeman was that in order to survive, a company needs that its stakeholder groups give their support to its corporate objectives; and in order to formulate suitable objectives, executives need to take concerns of these stakeholder groups into account (Lepineux, 2004). Freeman then proposed a broader, now classic definition of the stakeholder concept as any group or individual who can affect or is affected by the achievement of the organization's objective (Freeman, 1984). Stakeholders were first defined as those groups without whose support the organization would cease to exist (Freeman, Harrison, \& Wick, 2007). The shareowners, employees, customers, suppliers, lenders and society are included in the list of stakeholders (Lepineux, 2004). Stakeholders have also been defined to include those whose relationship to the enterprise cannot be completely contracted for, but upon whose cooperation and creativity depends for its survival and prosperity (Cheng \& Fan, 2010).

Thus, societal stakeholders comprise three intermediate categories: global society, national societies, and social groups or institutions. Similarly business stakeholders include three kinds of actors: shareholders, internal stakeholders, and external business stakeholders. The last of classification consists of a developed typology of the stakeholder spectrum. The main societal stakeholders are: global society, civil societies of the countries where a company is located and/or operates, local communities surrounding its establishments, international institutions, governments, activist groups, non-governmental organizations, civic associations, and the media. The main business stakeholders are: shareholders, executives and managers, employees and workers, trade 
unions, customers, suppliers, subcontractors, banks, investors, competitors, and business organizations (Lepineux, 2004; Ratanajongkol, Davey, \& Low, 2006).

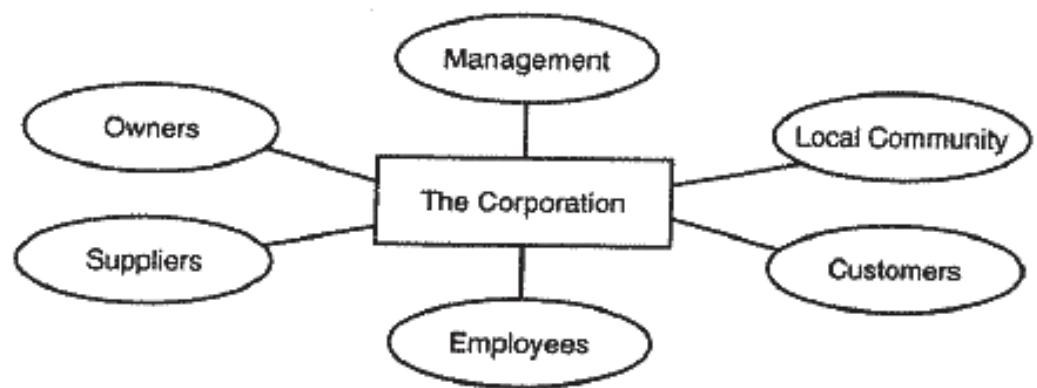

Figure 1.2: Chart of Stakeholder Theory

Source: Adopted from Freeman (1984)

From figure 1.2 above, the owners have financial stake in the corporation in the form of stocks, bonds, and so on, and they expect some kind of financial return from them. Employees have their jobs and usually their livelihood at stake. They often have specialized skills for which there is usually no perfectly elastic market. In return for their labor, they expect security, wages, benefits, and meaningful work. In return for their loyalty, the employees are expected to follow the instructions of management most of the time, to speak favorably about the company, and to be responsible citizens in the local communities in which the company operates. Suppliers, interpreted in a stakeholder sense, are vital to the success of the firm, for raw materials will determine the final product's quality and price. In turn the firm is a customer of the supplier and is therefore vital to the success and survival of the supplier. Customers exchange resources for the products of the firm and in return receive the benefits of the products. Customers provide the lifeblood of the firm in the form of revenue. The local community grants the firm the right to build facilities and, in turn, it benefits from the tax base and economic and social contributions of the firm. In return for the provision of local services, the firm is expected to be a good citizen, as is any person, either "natural or artificial." Management's stake is like that of employees, with some kind of explicit or implicit employment contract. But, on the other hand, management has a duty of safeguarding the welfare of the entity and ensuring the balancing of the multiple claims of conflicting stakeholders (Post, Preston \& Sachs, 2002).

In summary, stakeholder theory views corporate social, economic and ecological sustainability of a business as part of a social system by focusing on the interests of various stakeholder groups within the society where a business operates. The power of stakeholders and their expectations can change over time therefore companies have to continually adapt their operating and reporting behaviors. Above all, stakeholder theory does not give supremacy to one stakeholder group over another, though there will surely be times when one group will benefit at the expense of others. But, stakeholder theory suggests that companies will manage the relationships among the stakeholders based on different factors such as the nature of the task environment, the salience of stakeholder groups and the values of decision makers who determine the shareholder ranking process. However, management will tend to satisfy the information demands of those stakeholders that are important to the firms' ongoing survival so that firms would not respond to all stakeholders equally. In general, management must keep the relationships among stakeholders in balance. When these relationships become imbalanced, the survival of the firm is in jeopardy. Therefore, the stakeholder theory is relevant to this study.

\subsection{Empirical Review}

A research by Kearney (2009), done on 99 sustainability-focused organizations across 18 industries that were part of the Dow Jones Index to examine the impact of environmental activities on the performance of the organization and also to determine whether organizations with sustainable practices are more likely to withstand the economic recession. The research was for a period of six months and the analysis was done in two phases: a three-month phase and a six-month phase. The analysis revealed that during the current economic recession, organizations with practices are geared towards protecting the environment and improving the social well-being of the stakeholders while adding value to the shareholders have outperformed their industry peers financially. The financial advantage has resulted from reduced operational costs (energy and water usage, etc.) and increased revenues from the development of innovative green products (Kearney, 2009).

Stark and Markey (2008) examined the impacts of entrepreneurship on the triple bottom line in rural communities. The study also analyzed the environmental impacts including a focus on preservation and restoration of the natural environment and heritage of the region, as well as changing attitudes toward engagement in sustainable development. Finally, to measure economic impacts, the study looked at the growth in the number of entrepreneurs, skill building increases in employment, creation of new markets, improved 
infrastructure, and tax revenues. The study found that a great diversity of indicators and measures was necessary to evaluate the impacts across the six programs they examined and provides a clear example of how specific indicators can be developed for triple bottom line projects.

\section{Research Methodology}

The study adopted a survey research design. The population of this study comprise the staff and customers of the three selected deposit money banks namely First Bank of Nigeria (FBN), United Bank for Africa (UBA) and the Access bank in Nigeria. The banks were selected for this study because of their greater use of the triple bottom line reporting as discovered from the review of their annual accounts and reports. The sample size is made up of 150 copies of the valid questionnaire returned by 80 bank staffs and 70 Consumers out of total number of 350 questionnaire distributed. This sample represents the stakeholders of the selected banks. A structured questionnaire of four point likert scale format of Strongly Agree (SA); Agree (A); Disagree (D); Strongly Disagree (SD) with associated weights of 4, 3, 2, 1 respectively was designed and used to collect the primary data. The validity of the research instrument was done through the use of expert in the field of Accountancy and a Cronbach's Alpha reliability test yielded a stability Co-efficient of $99.4 \%$ which was considered well enough for this study. The job status of the respondents was considered when the questionnaires were being administered. The opinions of respondents were sought by using descriptive statistics and the multiple regression models to confirm the hypotheses of this study at $1 \%$ significant level with the help of SPSS version.

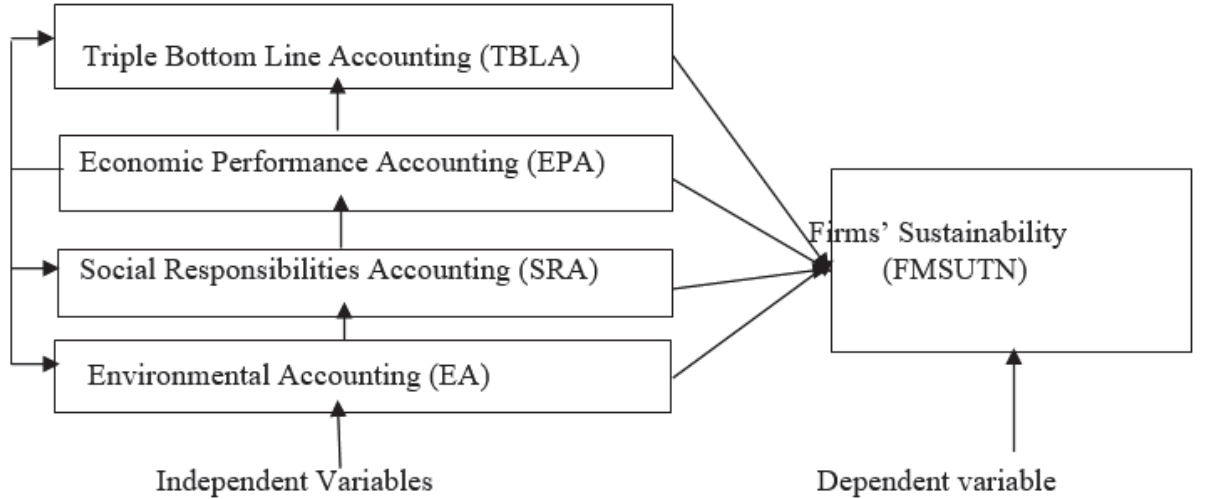

Figure 3.1: Conceptual Model of the Study

Source: Author's Compilation (2020)

The figure 3.1 above shows the conceptual model developed to show the impact of the independent variable of triple bottom line accounting (TBLA) on the dependent variable of firms' sustainability (FMSUTN). The independent of TBLA is made up of three explanatory independent variables of EPA, SRA and EA. Thus, the model gives the snapshot of the impact of TBL accounting on firms' sustainability in Nigeria.

\subsection{Model Specification and Identification of Variables}

This study employed regression model of forensic accounting services and fraudulence practices adopted by Anuolam et al (2016) as follow:

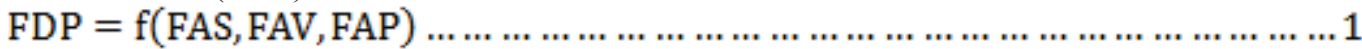

$$
\begin{aligned}
& \mathrm{FDP}=\mathrm{f}\left(\alpha_{0}+\beta_{1} \text { FAS }+\beta_{2}\right. \text { FAV }
\end{aligned}
$$

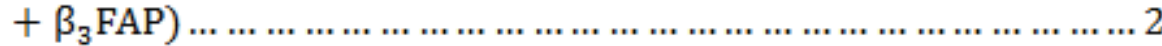

$$
\begin{aligned}
& \text { where: } \alpha_{0} \text { is constant and } \beta_{1}, \beta_{2}, \beta_{3}>0
\end{aligned}
$$

The dependent variable of fraudulent practices (FDP) was used as a function of the three components of independent variables of FAS (Forensic Accounting Services), FAV (Forensic Accounting Validation) and FAP (Forensic Accounting Practices). This study therefore replaced the variables used by Anuolam et al (2016) with a dependable variable of FMSUTN as a function of three predictable variables of EPA, SRA and EA to form the specific objectives and research hypotheses. The model is as follow:

FMSUTN $=f\left(\beta_{0}+\beta_{1} E P A+\beta_{2} S R A+\beta_{3} E A+U t\right) \ldots \ldots \ldots \ldots \ldots 2$

where: $\beta_{0}$ is constants, $U_{t}$ stochastic error term and $\beta_{1}, \beta_{2}, \beta_{3}$ are parameters $/$ coefficients.

\subsection{A priori Expectation}

There expected to be the impact of TBL accounting on firms' sustainability in Nigeria. This is symbolically demonstrated below:

$\beta_{1}, \beta_{2}, \beta_{3},>0$ 


\section{Data presentation and Analysis}

Table 4.1 Category of Respondents * Job Status Cross-tabulation

\begin{tabular}{|ll|r|r|r|r|}
\hline & & \multicolumn{3}{|c|}{ Job Status } & \multirow{2}{*}{ Total } \\
\cline { 3 - 5 } & & Accountants & Managers & \multicolumn{1}{c|}{ Customers } & \\
\hline \multirow{2}{*}{ Category of Respondents } & Bank Staffs & 47 & 33 & 0 & 80 \\
Total & Bank Customers & 0 & 6 & 64 & 70 \\
\hline
\end{tabular}

Source: Author's Computation (2020)

The total number of 150 respondents is made up of 47 accountants, 39 managers and 64 customers in term of job status of which 80 are the banks staffs and the remaining 70 are their customers. As disclosed in the above table 4.1

Table 4.2 Reliability Statistics Test

\begin{tabular}{|r|ll|}
\hline Cronbach's Alpha & N of Items & \\
\hline
\end{tabular}

Source: Author's Computation (2020)

Table 4.2 above showed Cronbach's Alpha coefficient of 0.994 which above the value of Cronbach's Alpha coefficient recommended by George and Mallery (2003) that the statistical reliability value is expected be 0.70 or above. This indicates that the questionnaire is reliable.

Table 4.3 Regression Model Summary

\begin{tabular}{|l|r|r|l|l|}
\hline Model & R & R Square & Adjusted R Square & Std. Error of the Estimate \\
\hline 1 & $.993^{\mathrm{a}}$ & .986 & .986 & .10655 \\
\hline
\end{tabular}

Source: Author's Computation, 202)

Predictors: (Constant), EPA = Economic Performance Accounting, EA = Environmental Accounting, SRA $=$ Social Responsibility Accounting. Table 4.3 above indicates that the coefficient of relationship (R) (0.993) for the hypotheses at a significant level of 0.01 shows a strong relationship. Then the coefficient of determination $\left(\mathrm{R}^{2}\right)(0.986)$ shows a moderate positive correlation of the studies variables, which indicates that about $98.6 \%$ of variation in the dependent variable firms' sustainability is explained by the independent variables of triple bottom line accounting or the ability of the regression line to predict dependent variable (FCs) is about $98.6 \%$. The other $1.2 \%$ is explained by other factors outside the model and the error term. Thus, null hypothesis is rejected and alternative hypotheses accepted. Thus, triple bottom line accounting has significance impact on firms' sustainability in Nigeria.

Table 4.4 Regression Analysis of Variance (ANOVA)

\begin{tabular}{|ll|r|l|l|l|l|}
\hline Model & & Sum of Squares & df & Mean Square & F & Sig. \\
\hline \multirow{3}{*}{1} & Regression & 119.736 & 3 & 39.912 & 3515.629 & $.000^{\mathrm{b}}$ \\
& Residual & 1.657 & 146 & .011 & & \\
& Total & 121.393 & 149 & & & \\
\hline
\end{tabular}

Source: Author's Computation, 202)

Dependent Variable: FMSUTN = Firms' sustainability b. Predictors: (Constant), EA, EPA, SRA

In table 4.4 above, $f=3515.63$ and $p$-value of $0.00<0.01$. This mean null hypothesis should also be rejected. Therefore, BLT accounting has significant impact on firms' sustainability in Nigeria.

Table 4.5 Regression Coefficients

\begin{tabular}{|c|c|c|c|c|c|c|}
\hline \multirow{2}{*}{\multicolumn{2}{|c|}{ Model }} & \multicolumn{2}{|c|}{ Un-standardized Coefficients } & \multirow{2}{*}{$\begin{array}{c}\text { Standardized } \\
\text { Coefficients }\end{array}$} & \multirow[t]{2}{*}{$\mathrm{t}$} & \multirow[t]{2}{*}{ Sig. } \\
\hline & & $\mathrm{B}$ & Std. Error & & & \\
\hline \multirow{4}{*}{1} & (Constant) & -.009 & .036 & & -.265 & .792 \\
\hline & EPA & .416 & .042 & .417 & 9.951 & .000 \\
\hline & SRA & .490 & .057 & .485 & 8.592 & .000 \\
\hline & EA & .097 & .044 & .100 & 2.182 & .031 \\
\hline
\end{tabular}

Source: Author's Computation (2020)

Dependent Variable: FMSUTN = Firms' sustainability

The result from table 4.5 above, the predictor variables of economic performance accounting (EPA) where $t$ $=9.951$, and $p=0.00<0.01$; social responsibility accounting $($ SRA) where $t=8.592$, and $p=0.00<0.01$ and environmental accounting (EA) where $\mathrm{t}=2.182$, and $\mathrm{p}=0.00>0.31$ all showed significant positive relationship with dependent variable of firms' sustainability. Also, based on the linear equation of the predictor variables 
coefficients, that is: FMSUTN $=-0.009+0.416 b_{1}+0.490 b_{2}+0.097 b_{3}+U t$, the equation depicted that the impact of firms' sustainability in Nigeria is determined by $1 \%$ increase in each of the triple bottom line accounting explanatory variables of EPA, SRA and EA.

\section{Discussion of Results}

The coefficient of relationship (R) of 0.993 for the hypotheses at a significant level of 0.01 showed a strong relationship and the coefficient of determination $\left(R^{2}\right)(0.986)$ shows a moderate positive correlation of the studies variables, which indicates the ability of the regression line to predict dependent variable (FMSTN) is about $98.6 \%$. The other $1.4 \%$ is explained by other factors outside the model and the error term. The p-value of $0.00<0.01$, thus, null hypothesis is rejected and alternative hypotheses accepted. Thus, the impact of firms' sustainability can be determined through the practices of triple bottom line explanatory variables of EPA, SRA and EA in the Nigerian. Then, the regression line of FMSUTN $=-0.009+0.416 b_{1}+0.490 b_{2}+0.097 b_{3}+U t$ also indicated that given a unit increase in the impact of triple bottom line accounting will lead to the sustainability of firms in Nigeria. So far, all the results from this study therefore, indicated that accounting for economic, social and environmental activities of firms will enhance their sustainability and survival.

\section{Conclusion and Recommendations}

This disclosure in form of TBL accounting becomes a necessity to satisfy the interest of varying stakeholder groups. The era of a single monopolistic view of business performance from only the economic perspective has long gone. Firms now need to attend to the needs of varying and divergent of stakeholder groups. The TBL accounting concept developed by John Elkington is a suggested that can place sustainability objective at the fore front of present day business. The sustainability of firms requires that organizations should adapt reporting systems that will provide triple bottom line information to the firms' stakeholders. This study is based on an empirical assessment of stakeholders' perception of the impact of triple bottom line accounting on firms; sustainability in Nigeria. The results obtained from the analysis of data collected through questionnaire exhibited full support of stakeholders in the use of triple bottom line reports as a basis for determining the sustainability of firms and assessing the organizations' impact in the society as well. This study, based on the findings, recommends that firms should adopt transparent disclosure of quantifiable triple bottom line accounting encompassing social, environmental and economic performance as this would boost stakeholder's confidence and improve the overall quality of their report. Also, the performance information reported by firms should be linked with their stated intentions and their strategic processes for achieving sustainability, as these would ultimately capture their impact in the society and boost their reputation. More so, firms should always adopt stakeholder integrated approach in the preparation of their triple bottom line report as this would significantly improve the transparency level of their report, in addition to boosting stakeholders' confidence in the report. As most of the developed countries have various forms of standards regulating social and environmental disclosure, the governments of developing countries are also encouraged along with standard setting bodies to develop standards that can guide every organization in accounting for social and environmental impacts. As the concept of triple bottom line replaces corporate social responsibility, additional education and training should be given to accountants on the key trends of economic, social and environmental disclosure so as to keep them abreast of changes in the profession.

\section{Acknowledgment}

We wish to thank and appreciate the effort of Dr. F. O. Olaoye, Prof. G. T. Akinleye and Dr. C. O. Olaoye of Accounting Department, Ekiti State University, Ado-Ekiti, Nigeria.

\section{Declaration}

We, the aforementioned declare that the article sent for publication in your journal has not been published or submitted for printing at any other publisher. The content of the article does not infringe the copyright, legal or material interest of other persons.

We declare that we are familiar with the principle of plagiarism which in this case does not apply.

We declare that we have written the article independently.

\section{Disclosure statement}

No potential conflict of interest was reported by the authors. We also give my consent for publishing the article on the Publisher's website and any other institutional repository.

1. Mr. A. A. Olaoye

2. Dr. E. T. Olatunji

\section{REFERENCES}

Adams, C.,Frost, G., \& Webber, W. (2004). Triple bottom line: A review of the literature. In a Henriques \& J. 
Richardson (Eds.). 7he triple bottomline: Does it all add up? (pp. 17-25). London: Earthscan.

Amos, O. A., Uniamikogbo E. and Atu, O. G. (2016). Sustainability and triple bottom line: An overview of two interrelated concepts: Igbinedion University Journal of Accounting, Vol. 2, 45-89.

Anuolam, O. M,, Onyema, T. E. \& Ekeke, U. (2016). Forensic accounting and financial crimes: Adopting the inference, relevance and logic solution approach. West African Journal of Industry and Academic Research, 17, 126-132.

Ballou, B., Heitger, D.L. \& Landes, C.E. (2006). The future of corporate sustainability reporting. Journal of Accountancy, Available at http://referensi.dosen.narotama.ac.id/files/2012/01/The-Future-ofCorporate-Sustainability.pdf.

Cheng, L. H., \& Fan, H. K. (2010). Drivers of environmental disclosure and stakeholder expectation: Evidence from Taiwan. Journal of Business Ethics, 96, 435-451.

Crowther, D. (2000). Social and environmental accounting. London: Financial Times Prentice Hall.

Deegan, C. (2001). Financial accounting theory. Roseville, NSW: McGraw-Hill Book Company Australia Pty Limited.

Elkington, J. (1994). Cannibals with forks: the triple bottom line of 21st century business. British Columbia: New Society Publishers.

Elkington, J. (1997). Cannibals with forks - Triple bottom line of 21st century business. Stoney Creek, CT: New Society Publishers.

Elkington, J. (1997). Cannibals with Forks: the TBL of the 21st century business: Oxford, Capstone.

Elkington, J. (1998). Cannibals with forks: 1he triple bottom line o/21" century business. Gabriela Island, BC: New Society Publishers.

Faux, J. (2004). A Theoretical Perspective of Triple Bottom Line Reporting and Issues of Performance and Disclosure in the Australian Tourism and Hospitality Industry, Business Enterprises and Sustainable Travel (BEST) Think Tank IV, Sustainability and Mass Destinations: Challenges and Possibilities, Conference Proceedings, Esbjerg, Denmark.

Freeman, R. E. (1984). Strategic Management: A Stakeholder Approach. USA: Pitman Publishing Inc.

Freeman, R. E., Harrison, J.E., \& Wick, A. C. (2007). Managing for stakeholders: survival, reputation and success. New Heaven, CT: Yale University Press.

Goel, P. (2010). Triple bottom line reporting: An analytical approach for corporate sustainability. Journal of Finance, Accounting, and Management, 1(1), 27-42.

Global Reporting Initiative (GRI), (2000). Sustainability Reporting Guidelines: European Journal of Accounting Auditing and Finance Research Vol.3, No.3, pp.45-61.

Ho, L., \& Taylor, M. (2007). An empirical analysis of triple bottom-line reporting and its determinants: Evidence from the United States and Japan. Journal of International Finance Management and Accounting, $18(2), 123-156$.

Isaksson, R. (2005). Economic Sustainability and the Cost of Poor Quality.Corporate Social Responsibility and Environmental Management, 12, 197-209.

Jasch, C. \& Stasiskiene, Z. (2005). From Environmental management Accounting to Sustainability management Accounting: Journal of Environmental research, engineering and management, 34(4), 77 - 88.

Kearney, A. (2009). "Green" winners: The performance of sustainability-focused organization during the financial crisis.http://www.sustaincommworld.com/pdfs/ATKearney_Green_W innerspdf.

Lepineux, F. (2004). Stakeholder Theory, Society and Social Cohesion. Centre for the Management of Environmental and Social Responsibilities (CMER) - INSEAD, Working Paper Series, 1 - 20.

Michael, M., Allan, C. \& Penny, D. (2008). Evaluating the Process of Triple Bottom Line Reporting: Increasing the Potential for Change: Institute for Land, Water \& Society, Charles Sturt University, Albury NSW, Australia Author Posting. (c) Taylor \& Francis.

Mintz, S. M. (2011). Triple bottom line reporting for CPAs. Ihe CPA Journal 81(12), 26-33.

Mish, J., \& Scammon, D. L. (2010). Principle-Based Stakeholder Marketing: Insights from Private TripleBottom-Line Firms. Journal of Public Policy \&Marketing, 29(1), 12-26.

Mitchell, M., Curtis, A., \& Davidson, P. (2008). Evaluating the Process of Triple Bottom Line Reporting; Increasing the Potential For Change. Local Environment, 13(2), 67-80.

Norman, W., \& MacDonal, C. (2004). Getting to the bottom of the triple bottom line. Business Ethics Quarterly, $2(14), 243-262$

Okafor, G.O., Okaro, S.C., \& Egbunike, F.C. (2013). Environmental Cost Accounting and Cost Allocation: A Study of Selected Manufacturing Companies in Nigeria. European Journal of Business and Management, $5(18), 68-75$.

Osisioma, B.C. (2010). Global Financial Crisis: Impact on the Changing Face of Accountancy Profession. Frontier Lecture Series 001, Department of Accountancy, Nnamdi Azikiwe University, Awka.

Onyali, C. I., Okafor, T. G. and Onodi B. (2015). Effectiveness of triple bottom line disclosure practice in 
Nigeria-stakeholders perspective: European Journal of Accounting Auditing and Finance Research. Published by European Centre for Research Training and Development UK, 3(3), 45-61.

Painter- Morland, M. (2006). Triple Bottom-Line Reporting as Social Grammar: Integrating Corporate Social responsibility and Corporate Codes of Conduct. Business Ethics: A European Review, 15(4), 352-364.

Perrini, F., \& Tencati, A. (2006). Sustainability and stakeholder management: the need for new corporate performance evaluation and reporting systems. Business Strategy and the Environment, 15(5), 296-308.

Post, J.E., Preston, L.E., Sachs S. (2002). Managing the extended enterprise: the new stakeholder view. California Management Review, 45(1), 6-28.

Ratanajongkol, S., Davey, H., \& Low, M. (2006). Corporate social reporting in Thailand, the news is all good and increasing. Qualitative Research in Accounting \& Management, 3(1), 67-83.

Richardson, J. (2004). Accounting for sustainability: Measuring quantities or enhancing qualities? In A. Henriques \& J. Richardson (Eds.). The triple bottom line: Does it all add up? (pp. 34-44). London: Earthscan.

Rogers, K., \& Hudson, B. (2011). The triple bottom line: The synergies of transformative perceptions and practices of sustainability. OD Practitioner, 4(43), 3-9.

Suttipun, M. (2012). Triple Bottom Line Reporting in Annual Reports: A Case Study of Companies Listed on the Stock Exchange of Thailand (SET). Asian Journal of Finance \& Accounting, 4(1).

Skouloudis, A., Evangelinos, K., \& Kourmousis, F. (2009). Development of an Evaluatio Methodology for $\mathrm{n}$ Igbinedion University Journal of Accounting, 2, 1-25

Slaper, T. F., \& Hall, T. J. (2011). The triple bottom line:What is it and how does it work? Indiana Business Review, 86(1), 4-8.

Spangenberg, J. (2005). Economic sustainability of the economy: Constructs and indicators. International Journal of Sustainable Development, 8(1/2), 47-64.

Wang, L., \& Lin, L. (2007). A Methodology Framework for the Triple Bottome LineAccounting and Management of Industry Enterprises. Internaltional Journal of Production Research,45(5), 1063-1088. 